\title{
PENGGUNAAN SARI UMBI BAWANG MERAH DALAM PEMBIBITAN PAPAYA
}

\author{
Faryska Nur Ichsan"), Djoko Purnomo ${ }^{2)}$ dan Linajanti Darsono ${ }^{2)}$ \\ ${ }^{1)}$ Mahasiswa Program Studi Agroteknologi Fakultas Pertanian UNS \\ ${ }^{2}$ Program Studi Agroteknologi Fakultas Pertanian UNS \\ Email: faryskanur_ichsan@yahoo.com
}

\begin{abstract}
Community awareness in healthy life is increasing by consuming nutritious food through such as fruit. So it is necessary for increasing the availability of fruit either by cultivation expansion or technology development. The production life of papaya crop approximately three years only, so that replanting takes relatively fast. But there is some limitations mainly the availability of suitable seedling (age and uniformity). For improving the availability of suitable papaya seedling can be used gibberellin as growth regulator substance. But gibberellin in pure analysis limitations are expensive, not always available, and high technology in application. The aim of the research was to test of shallot juice (1 $\mathrm{kg}$ of shallot bulbs destroyed by juicer) as gibberellin substitute for improving papaya seedling. The experiment was conducted at terrace house, consist of percentage and speed of germination and growth of seedling observation after seed soaked 2 hours in shallot juice several concentration treatment. Test of the germination percentage and speed conducted for 10 seeds on pastur paper in petridish (11.5 diameter) as germination media. The experiment for growth seedling was arranged in randomized completely design which the treatments are: seed soaked in water, soaked in 5, 10, 15, dan $20 \mathrm{ml} \mathrm{l}^{-1}$ shallot juice concentration, and soaked in gibberellin $10 \mathrm{ppm}$. Each of the experiment unit consist of 8 seedlings which planted on trypot (composite of plastic pots by size $5.5 \times 5.5 \mathrm{~cm}$ at surface, $5.5 \mathrm{~cm}$ height, and 2,5x2,5 cm at the base, each of traypot consist of 32 pots). So in each of tray pot there are 8 experimental units, each of experimental unit repliclated 3 times. Traypot and petridish at terrace house shaded by woven plastic $65 \%$, by size $2.5 \times 1.5 \times 2.0 \mathrm{~m}$ (length, width, and height). Yield of the research showed that shallot juice potential as gibberellin replacement in papaya nursery. Response of papaya seed (percentage and speed of germination) and seedling (length of root, stem diameter, number of leafs, leaf area, and weight of biomass) to $15 \mathrm{ml} \mathrm{l}^{-1}$ shallot juice equal with gibberellin 10 ppm.
\end{abstract}

Keywords: Bed-Shallot, Bulb Juice, Papaya-Seedling

\section{PENDAHULUAN}

Pepaya (Carica papaya L.) merupakan komoditas buah tropika utama, sangat bermanfaat bagi kesehatan. Karena kondisi lingkungan yang memadai, maka Indonesia termasuk lima besar negara produsen utama buah papaya. Papaya sebagai komoditas hortikultura memiliki berbagai keunggulan, seperti cepat berproduksi, berbuah sepanjang tahun, dan tidak memerlukan lahan penanaman luas, sehingga dapat ditanam di pekarangan. Papaya bermanfaat bagi daya tahan tubuh didaerah tropis, karena kandungan vitamin, mineral, dan serat, tidak berasa masam. Oleh karena itu papaya dapat dikonsumsi oleh manusia semua usia tidak mempengaruhi kemasaman lambung (Sobir, 2010). Manfaat besar mengakibatkan permintaan buah papaya makin tinggi sehingga terbuka luas peluang usaha. Peluang usaha pepaya sejak dari penyediaan biji bahan tanam, bibit, dan sarana produksi, serta produksi. Ketersediaan bahan tanam sangat diperlukan selain untuk perluasan tanam juga karena masa produktif tanaman papaya hanya sekitar tiga tahun, sehingga peremajaan terus diperlukan. Oleh karena itu bibit pepaya diperlukan dalam jumlah besar dengan waktu yang relatif pendek. Bibit yang tumbuh serempak, cepat, dan sehat diperlukan dalam pertanaman papaya. Sampai saat ini bibit umur muda banyak digunakan, selain berakibat pada kualitas dan ketidak seragaman tanaman di lapangan juga tidak menguntungkan sebagai bidang usaha penyediaan bibit (harga jual rendah).

Secara morfologi biji pepaya belapis kulit (keputihan, lunak, dan agak bening) disebut sarcotesta. Pada sarcotesta terdapat senyawa fenolik yang menghambat perkecambahan benih (Chow dan Lin 1991), namun sarkotesta berfungsi menunda proses deteriorasi (Sari 2005). Agar biji papaya cepat 
berkecambah (biji tidak mengalami deteriorasi), sehingga bibit cepat tersedia dan tumbuh serempak dapat diusahakan menggunakan zat pengatur tumbuh. Zat pengatur tumbuh yang menginduksi perkecambahan adalah giberelin (Fosket 1994), terutama pematahan dormansi biji (Salisbury and Ross, 1992; Taiz and Zieger, 1998).

Untuk kalangan petani, giberelin yang tersedia (sintetis) relatif sulit diperoleh, mahal, dan perlu ketelitian tinggi dalam penggunaan. Bagi petani bermodal terbatas perlu alternatif pengganti giberelin yang mudah didapat dan selalu tersedia. Bawang merah diduga memiliki kandungan auksin (Ependi 2009), auksin dan giberelin (anonim 2009). Kandungan giberelin bawang merah diuji melalui penelitian Setyowati (2004) yang menunjukkan bahwa sari umbi bawang merah mampu memacu pertumbuhan panjang akar, panjang tunas, dan jumlah tunas pada stek mawar. Demikian pula Sekta (2005), dari penelitian pada stek cabe memperoleh bahwa, penggunaan sari larutan bawang merah memberikan pengaruh nyata tehadap panjang tunas, jumlah daun, tingkat kehijauan daun, dan berat kering tunas. Ekstrak bawang merah digunakan oleh Muswita (2011) untuk meningkatkan persentase setek hidup dan jumlah akar gaharu masing-masing dengan konsentrasi 1,0 dan $0,5 \%$. Penelitian ini bertujuan memperoleh jawaban 1) apakah jus umbi bawang merah dapat berperan dalam perkecambahan dan pertumbuhan bibit papaya serupa giberelin, 2) berapa konsentrasi jus umbi bawang merah diperlukan dalam perkecambahan dan pertumbuhan bibit papaya. Penelitian diharapkan memperoleh jawaban sehingga bermanfaat dalam peningkatan teknologi pembibitan papaya.

\section{METODE PENELITIAN}

Penelitian dengan metode percobaan dilaksanakan pada bulan Mei sampai dengan Oktober 2013 bertempat di lokasi dengan posisi geografi $7^{\circ} 30^{\prime} 8725^{\prime \prime}$ LS dan $110^{\circ} 36^{\prime} 0967$ ' BT, tinggi tempat $455 \mathrm{~m}$ dpl dan di laboratorium Fisiologi dan Bioteknologi Tanaman. Biji papaya adalah hasil buah dari tanaman papaya kultivar Boyolali berasal dari varietas Thailand yang sudah beradaptasi. Uji daya dan kecepatan berkecambah (terhadap 10 biji, masing-masing diulang 3 kali) menggunakan cawan petri (diameter 11,5 cm) yang didalamnya terdapat kertas pastur (buram) sebagai alas biji dan penjaga kelembaban. Biji papaya diambil dari bagian tengah buah telah masak (warna merah hampir merata) (Kamil 1979), setelah sarkotesta dihilangkan (dipilin bercampur abu dapur) kemudinan dibilas dengan air, setelah itu dikeringkan selama 2 hari di bawah sinar matahari. Biji saat akan ditanam (uji daya kecambah maupun pertumbuhan) direndam dalam larutan perlakuan selama 2 hari hingga semua biji tenggelam.

Sebagai media pembibitan adalah traypot (gabungan pot plastik berisi tanah, ukuran setiap pot, di permukaan $5,5 \times 5,5 \mathrm{~cm}$, tinggi $5,5 \mathrm{~cm}$, dan dasar pot $2,5 \times 2,5 \mathrm{~cm}$, setiap traypot terdiri atas 32 pot). Dengan demikian setiap traypot terdapat 8 satuan percobaan, setiap satuan percobaan diulang 3 kali. Tanah media pembibitan dari jenis tanah regosol yang telah diayak (diameter ayakan $2 \mathrm{~mm}$ ) dan dicampur pupuk kandang sapi yang telah terdekomposisi (bentuk asli kotoran beserta bahan lain tidak tampak lagi), perbandingan $2: 1$. Pot dalam traypot diisi tanah hingga penuh (rata di permukaan) dengan kepadatan sedang. Larutan bawang merah berasal dari $1 \mathrm{~kg}$ umbi dimasukkan dalam juicer. Cairan hasil pengoperasian juicer (jus bawang merah) kemudian diencerkan sesuai perlakuan. Konsentrasi jus bawang merah berdasar penelitian pendahuluan berupa uji daya kecambah 15 biji pepaya dalam larutan dari 2 hingga $100 \%$. Hasil penelitian di atas memperoleh bahwa biji pada jus bawang merah konsentrasi 2 dan 4\%, daya kecambah mencapai $80-86,67 \%$. Oleh karena itu konsentrasi jus bawang merah dalam penelitian ini berkisar 0,5 hingga 2,0\%.

Rancangan penelitian adalah rancangan acak lengkap (RAL) dengan faktor tunggal, satu faktor dengan perlakuan air, jus bawang merah konsentrasi 5, 10, 15, dan $20 \mathrm{ml} \mathrm{l}^{-1}$, serta giberelin $10 \mathrm{ppm}$. Setiap perlakuan (satuan percobaan) terdiri atas 8 bibit yang ditanam diatas traypot. Traypot dan cawan petri diletakkan dibawah atap teras rumah dengan naungan paranet $65 \%$ berukuran $2,5 \mathrm{x}$ $1,5 \times 2,0 \mathrm{~m}$ (panjang, lebar, dan tinggi). Analisis untuk daya dan kecepatan berkecambah secara deskriptif, sedangkan untuk pertumbuhan bibit menggunakan analisis ragam, jika perbedaan nyata terjadi diteruskan dengan uji Duncan 0,95, juga uji 
korelasi. Pengamatan terdiri atas daya kecambah (kecambah umur 21 hari), kecepatan kecambah (kecambah umur 14 hari), panjang akar, diameter batang, tinggi bibit, karakter daun (jumlah dan luas), dan biomassa (karakter pertumbuhan diamati saat akhir penelitian, umur 48 minggu).

\section{HASIL DAN PEMBAHASAN}

\section{Perkecambahan biji}

Daya kecambah (DK) dan kecepatan berkecambah (KB) adalah tolok ukur mutu biji sebagai bahan tanam. Kedua hal tersebut menunjukkan potensi biji untuk tumbuh sebagai individu baru, cepat, dan tumbuh serempak di pertanaman. Semakin cepat biji berkecambah, semakin cepat tersedia sebagai bahan tanam. Pada umumnya kecepatan berkecambah ditentukan berdasarkan suatu hari saat $60-70 \%$ biji sudah berkecambah. Jus bawang merah konsentrasi 15 dan $20 \mathrm{ml} \mathrm{l}^{-1}$ mengakibatkan biji berkecambah sebesar $60 \%$ sekitar 13-14 hari. Ini lebih cepat 3-6 hari daripada biji yang sebelumnya direndam dalam akuades atau jus bawang merah konsentrasi 5 dan $10 \mathrm{ml} \mathrm{l}^{-1}$. Kecepatan ini sama dengan biji yang direndam dalam giberelin konsentrasi 10 ppm (gambar 1). Ini berarti bahwa jus bawang merah konsentrasi 15 hingga $20 \mathrm{ml} \mathrm{l}^{-1}$ memiliki kandungan giberelin setara konsentrasi $10 \mathrm{ppm}$. Kemungkinan lain adalah jus bawang merah konsentrasi 15 hingga $20 \mathrm{ml} \mathrm{l}^{-1}$ sebagai pengaktif giberelin biji papaya endogen. Setyowati (2004) melaporkan bahwa pemberian sari umbi bawang merah mampu memicu pertumbuhan panjang akar, panjang tunas, dan jumlah tunas pada stek mawar. Giberelin pada biji mendorong pemanjangan sel sehingga radikula dapat menembus endosperm kulit biji (Salisbury and Ross 1995), selain itu giberelin berperan dalam fase berkecambah dan akhir fase dormansi melalui pembentukan enzim $\alpha$ amilase (Hopkins 1995), dengan istilah lain giberelin dapat menghilangkan masa dormansi biji (Gardner dkk., 1991).

Daya berkecambah biji merupakan kemampuan biji untuk tumbuh dalam jangka waktu tertentu. Rentang waktu uji daya kecambah biji pepaya ditentukan 21 hari. Peran jus bawang merah terhadap daya kecambah biji pepaya belum tampak saat konsentrasi 5\% (tidak signifikan dengan biji direndam air). Pengaruh jus bawang merah tampak setelah mencapai konsentrasi 10-20 ml $1^{-1}$ yang meningkatkan daya kecambah antara 10 hingga 20\%. Namun peran jus bawang merah optimum adalah pada konsentrasi $15 \mathrm{ml}$ $1^{-1}$ (daya kecambah mencapai 90\%). Meskipun daya kecambah lebih rendah daripada biji yang direndam dalam giberelin $10 \mathrm{ppm}$ (mencapai 100\%), penggunaan jus bawang merah untuk meningkatkan daya kecambah telah tercapai, terutama konsentrasi $15 \%$ (gambar 1). Kecepatan berkecambah berkorelasi negatif dengan daya berkecambah $(\mathrm{r}=0,9)$, dapat dinyatakan bahwa biji semakin cepat berkecambah (hari yang diperlukan oleh biji berkecambah semakin singkat) semakin besar daya kecambah. Giberelin embrio biji yang berkecambah diperlukan untuk sintesis $\alpha$-amilase di lapisan aleuron dalam proses hidrolisis pati dalam endosperm (Taiz and Zieger 2010).

\section{Pertumbuhan bibit}

Saat biji berkecambah tumbuh akar, kemudian batang, dan daun. Panjang akar merupakan parameter pertumbuhan awal karena aktivitas pertumbuhan biji. Akar tumbuh memanjang dalam mempersiapkan penyediaan air dan hara (Sitompul dan Guritno 1995). Jus bawang merah konsentrasi $10-20 \mathrm{ml} \mathrm{l}^{-1}$ meningkatkan panjang akar (masing-masing dengan panjang 6,7, 8,1, dan $7,8 \mathrm{~cm}$ ). Panjang akar kecambah pada biji direndam air dan jus bawang merah konsentrasi $5 \mathrm{ml} \mathrm{l}^{-1}$ lebih rendah (5,4 dan $4,5 \mathrm{~cm}$ ), tertinggi adalah akar kecambah biji yang direndam giberelin $10 \mathrm{ppm}$, namun tidak berbeda nyata dengan biji yang direndan jus bawang merah $15 \mathrm{ml} \mathrm{l}^{-1}$ (gambar 2). Dengan demikian dari kecepatan berkecambah, daya berkecambah, hingga panjang akar, peranan jus bawang merah konsisten pada $15 \mathrm{ml} \mathrm{l}^{-1}$, yang setara dengan giberelin $10 \mathrm{ppm}$. Peranan konsentrasi beserta jumlah zat pengatur tumbuh (Omon 2008) atau substansi yang mengandung zat pengatur tumbuh untuk pertumbuhan tanaman, tidak terkecuali sistem perakaran, sangat penting.

Apakah pertumbuhan akar menunjang pertumbuhan selanjutnya, tampak pada diameter batang. Diameter batang sebagai salah satu tolok ukur pertumbuhan tanaman di atas media tanam (Ashari 1995), tampak bahwa diantara biji yang direndam jus bawang merah 10 hingga $20 \mathrm{ml} \mathrm{l}^{-1}$ dan giberelin 
10 ppm tidak berbeda nyata $(0,31-0,34 \mathrm{~cm})$. Angka tersebut lebih besar daripada tanaman berasal dari biji yang direndam air dan jus bawang merah $5 \mathrm{ml} \mathrm{l}^{-1}(0,3 \mathrm{~cm})$ (gambar 2). Melalui uji korelasi pajang akar bergubungan erat dengan diameter batang (korelasi positif, $\mathrm{r}=0,83$ ), berarti panjang akar berperan dalam pertumbuhan tanaman muda. Absorpsi air dan unsur hara dilanjutkan proses fotosintesis menghasilkan asimilat yang saat perumbuhan sebagian besar terakumulasi dalam organ tanaman selain sebagai substrat respirasi. Oleh karena itu diamerter batang selalu berkaitan dengan panjang akar (Mardani 2008).

Daun sebagai organ fotosintesis tumbuh dari tunas pada buku di batang. Daun yang berkisar 6 hingga 9 helai dan berkorelasi positif dengan diameter batang $(r=0,64)$ berarti gangguan yang berarti pada pertumbuhan tidak terjadi. Jumlah daun diantara tanaman yang berasal dari biji yang direndam air dan jus bawang merah hampir sama (berkisar 6 hingga 7 helai), hanya tanaman yang berasal dari biji direndam giberelin $10 \mathrm{ppm}$, mencapai jumlah daun sekitar 9 helai (gambar 3). Fakta menunjukkan bahwa diameter batang sekitar $0,3 \mathrm{~cm}$ pada semua perlakuan, namun jumlah daun lebih banyak pada tanaman berasal dari biji direndam giberelin 10 ppm. Ini mengindikasikan bahwa tanaman dari biji direndam giberelin $10 \mathrm{ppm}$ memiliki buku lebih banyak karena tinggi tanaman hampir sama (data tidak tercantum). Buku lebih banyak padahal tinggi tanaman hampir sama, berarti ruas lebih pendek. Peristiwa ini kemungkinan sama dengan yang terjadi pada tanaman tebu saat suhu rendah di musim dingin (Taiz and Zieger 2006).

Kuantitas cahaya dapat ditangkap kemudian diabsorpsi daun tergantung cahaya dan karakter daun. Salah satu karakter sebagai indikator jumlah cahaya dapat ditangkap adalah luas permukaan daun yang bila tanaman merupakan populasi dinyatakan dengan indeks luas daun (ILD), yakni perbandingan luas semua daun pada tajuk tanaman dibanding dengan luas lahan tempat tanaman tumbuh. Pembibitan tanaman dilakukan di lahan yang relatif terbatas sehingga karakter daun (luas) dinyatakan secara individual. Luas daun bibit papaya meningkat pada tanaman yang berasal dari biji yang direndam jus bawang merah 15 dan 20

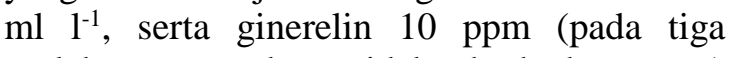
perlakuan tersebut tidak berbeda nyata) (gambar 3). Luas daun menentukan sebagian besar laju fotosintesis per tanaman, oleh karena itu melalui parameter tersebut informasi tentang fotosintesis tanaman dapat diperoleh (Sitompul dan Guritno 1995). Korelasi positif antara jumlah dan luas daun relatif tinggi $(\mathrm{r}=0,75)$. Namun, dengan jumlah daun pada bibit papaya berasal dari biji yang direndam dalam jus bawang merah 15 dan $20 \mathrm{ml} \mathrm{l}^{-1}$ yang relatif lebih sedikit, sedangkan luas daun tidak berbeda nyata, berarti secara individual daun bibit tersebut relatif lebih luas dari pada bibit berasal dari biji direndam giberelin $10 \mathrm{ppm}$.

Efektifitas daun dalam mengabsorpsi cahaya sehingga laju fotosintesis tinggi terekspresikan dalam biomassa. Uji korelasi menunjukkan bahwa luas daun berhubungan sangat erat $(\mathrm{r}=0,97)$ dengan biomassa. Konsentrasi jus bawang merah 15 dan $20 \mathrm{ml} \mathrm{l}^{-1}$, berpengaruh sangat nyata meningkatkan biomassa bibit papaya (biomassa $0,90-0,10 \mathrm{~g} \operatorname{tanaman}^{-1}$ ). Peningkatan biomassa juga terjadi pada bibit berasal dari biji direndam giberelin $10 \mathrm{ppm}$ (tidak berbeda nyata dengan konsentrasi $15 \mathrm{ml}$ $\left.1^{-1}\right)$ (gambar 4). Daun bibit yang berasal dari biji direndam pada tanaman jus bawang merah 15 dan $20 \mathrm{ml} \mathrm{l}^{-1}$ lebih luas daripada biji direndam giberelin $10 \mathrm{ppm}$, tetapi biomassa lebih rendah. Ini menunjukkan bahwa efektifitas fotosintesis bibit yang berasal dari jus bawang merah 15 dan $20 \mathrm{ml} \mathrm{l}^{-1}$ lebih rendah. Daun lebih luas tetapi efektifitas fotosintesis lebih rendah berarti absorpsi cahaya dibawah optimum. Namun dapat diduga bahwa hal ini (efektifitas fotosintesis bibit yang berasal dari sari larutan bawang merah 15 dan $20 \mathrm{ml} \mathrm{l}^{-1}$ lebih rendah) bukan merupakan kendala yang berarti untuk pertumbuhan selanjutnya. 


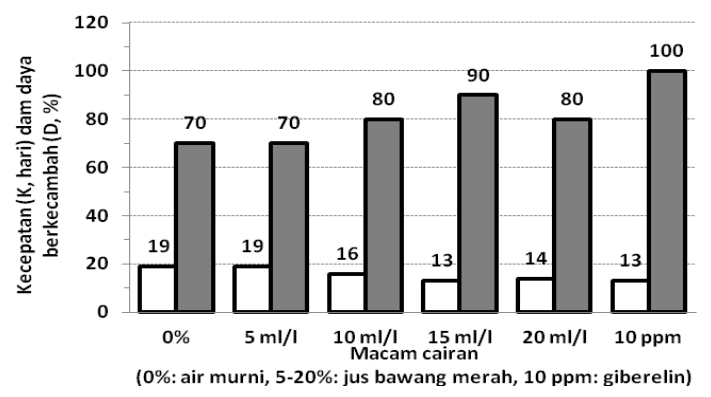

Gambar 1. Kecepatan berkecambah (pada 14 hari) dan daya berkecambah (pada 21 hari)

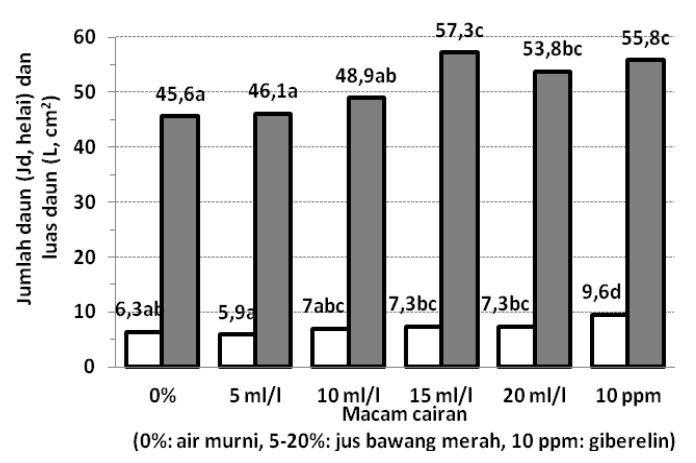

Gambar 3. Jumlah dan luas daun

\section{KESIMPULAN}

Jus bawang merah potensial digunakan sebagai pengganti zat pengatur tumbuh giberelin dalam pembibitan papaya. Tanggapan bibit papaya terhadap jus bawang merah konsentrasi $15 \mathrm{ml} \mathrm{l}^{-1}$ setara dengan giberelin $10 \mathrm{ppm}$, terjadi pada perkecambahan (daya dan kecepatan berkecambah) dan pertumbuhan bibit (panjang akar, diameter batang, jumlah daun, luas daun, dan bobot biomassa)

\section{DAFTAR PUSTAKA}

Ashari, S. 1995. Hortikultura Aspek Budidaya. UI-Press. Jakarta.

Fosket, D.E. 1994. Plant Growth and Development. A Molecular Approach. Academic Press. New York.

Gardner, P.F., R.B. Pearce, and R.L. Mitchell. 1991. Fisiologi Tanaman. Universitas Indonesia Press. Jakarta. 460 h.

Hopkins, W. G. 1995. Introduction to Plant Physiology. New York: John Wiley and Sons, Inc.

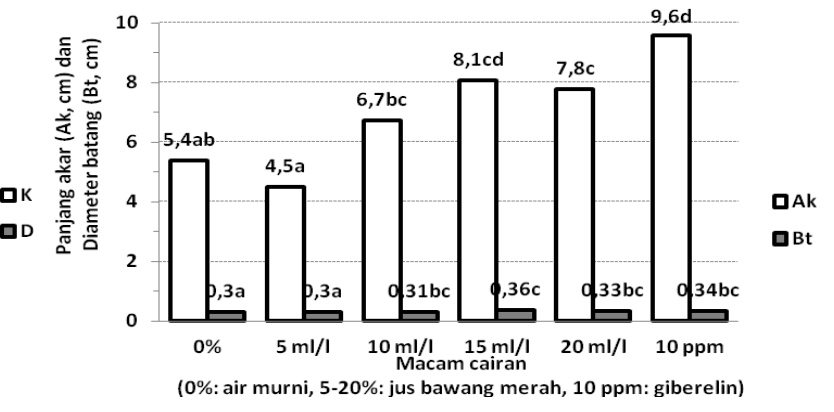

Gambar 2. Panjang akar dan diameter batang

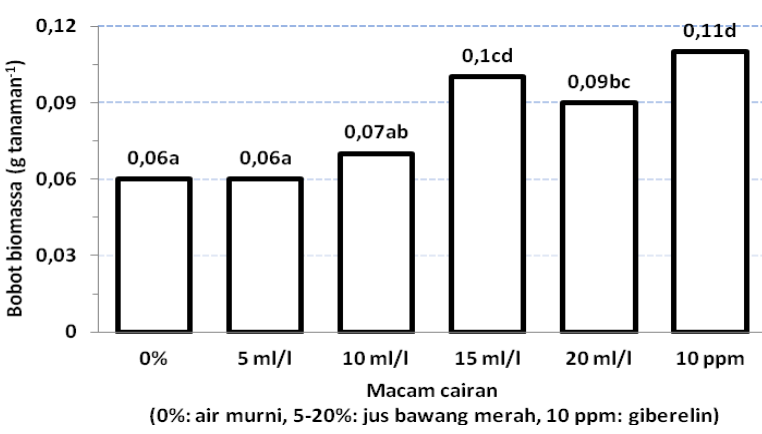

Gambar 4. Bobot biomassa

Muswita. 2011. Pengaruh konsentrasi bawang merah (Alium cepa l.) Terhadap pertumbuhan setek gaharu (Aquilaria malaccencis OKEN) . Skripsi. Program Studi Pendidikan Biologi, Fakultas Keguruan dan Ilmu Pendidikan, Universitas Jambi Kampus Pinang Masak, Mendalo Darat, Jambi

Omon, R. M, dkk 2002. Pembiakkan vegetatif dengan stek batang untuk jenis shorea of plyndra pada media air. Balai Penelitian Kehutanan Samarinda.

Salisbury, F.B., C.W. Ross. 1992. Plant Physiology. Wadsworth Pub. Co. $4^{\text {th }}$ ed. Belmont. California.

Setyowati T., 2004. Pengaruh ekstrak bawang merah (Allium cepa l) dan ekstrak bawang putih (Allium sativum l) terhadap pertumbuhan stek bunga mawar (Rosa sinensis l). JIPTUMMPP. Kota Batu.

Sitompul, S. M. dan B. Guritno.1995. Analisis Pertumbuhan Tanaman. Gadjah Mada University Press. Yogyakarta.

Sobir. 2010. Sukses Bertanam Pepaya Unnggul Kualitas Supermarket. Agromedia. Jakarta 
Sutanto, R. 2002. Penerapan Pertanian Organik. Kanisius. Yogyakarta. 219 hal.

Taiz, L. dan E. Zeiger. 2006. Plant Physiology. The Benyamin/Cunmings Pub.Co. California.
Taiz, L. dan E. Zeiger. 2010. Plant Physiology online. $4^{\text {th }}$ ed. Created by Sinauer Associates Inc. 